\title{
Current Paradigm of Treatment for Pancreatic Neuroendocrine Tumor
}

\author{
Min Je Sung, Moon Jae Chung \\ Department of Internal Medicine, Yonsei University College of Medicine, Seoul, Korea
}

Pancreatic neuroendocrine tumor (PNET) refer to tumors originating from the islet of Langerhans and shows various prognosis based on the presence or absence of symptoms due to hormone secretion, the Ki-67 cell proliferation index, and the histologic grade, and according to the degree of disease progression defined by the tumor-node-metastasis (TNM) stage classification. The purpose of medical treatment for PNET is to control symptoms or inhibit tumor growth. Somatostatin analogues can be administered for the purpose of controlling symptoms caused by the secretion of specific hormones, and are accepted as effective drugs for inhibiting the progression of G1/G2 tumors based on World Health Organization (WHO) classification with a Ki67 cell proliferation index less than $20 \%$. Among the molecularly targeted agents, everolimus and sunitinib can be considered in patients with WHO G1/G2 PNET showing progression after somatostatin analog therapy. Cytotoxic chemotherapy is generally administered to patients with large tumor volume and rapidly progressing metastatic NET, and etoposide/cisplatin combination therapy has been considered as a standard treatment. For the patient group of Grade 3 PNET (well differentiated) newly classified by the WHO 2017 classification, guidelines for standard treatment have not yet been established. As it has been reported, studies are needed to evaluate the treatment response rate of somatostatin analogues or molecularly targeted therapies for the patient with Grade 3 PNET. It is important to consider a multidisciplinary approach with all possible treatment options including medical treatment, radical resection of primary or metastatic lesions, liver-directed therapies, and peptide receptor radionuclide therapy for the patients with PNET.

Korean J Pancreas Biliary Tract 2021;26(1):24-32

Keywords: Pancreatic neuroendocrine tumor, Gastro-enteropancreatic neuroendocrine tumor, Carcinoma, neuroendocrine, Medical treatment $\begin{array}{ll}\text { Received } & \text { Dec. 30, } 2020 \\ \text { Revised } & \text { Jan. 21, } 2021 \\ \text { Accepted } & \text { Jan. 25, } 2021\end{array}$

Corresponding author: Moon Jae Chung

Division of Gastroenterology, Department of Internal Medicine, Yonsei University College of Medicine,

50-1 Yonsei-ro, Seodaemun-gu, Seoul 03722, Korea

Tel. +82-2-2228-1981 Fax. +82-2-393-6884

E-mail; mjchung@yuhs.ac

ORCID: http://orcid.org/0000-0002-5920-8549

This is an Open Access article distributed under the terms of the Creative Commons Attribution Non-Commercial License (http:// creativecommons.org/licenses/by-nc/3.0/) which permits unrestricted non-commercial use, distribution, and reproduction in any medium, provided the original work is properly cited.

Copyright $\odot 2021$ by The Korean Journal of Pancreas and Biliary Tract

\section{서 론}

췌장신경내분비종양(pancreatic neuroendocrine tumor)은
랑게르한스 소도(islet of Langerhans)에서 기원한 종양을 의미하며, 췌장암에서 $2-3 \%$ 를 차지하는 드문 종양이다. ${ }^{1,2}$ 국내 자료를 살펴보면, 2000년에서 2009년까지 29개 병원에서 
조사한 위·장·췌장계 신경내분비종양(gastroenteropancreatic neuroendocrine tumors, GEP-NETs) 4,951명의 증례에서 췌장신경내분비종양은 $8.7 \%$ 의 비율로 관찰되었고, 최근 진단 기술의 발전함에 따라 발견 빈도가 해마다 증가하고 있다. ${ }^{3}$ 또한, 대한소화기암학회에서 2002년부터 2012년까지 15개 병원을 대상으로 조사한 GEP-NETs 2,345 증례 중 췌장신경내분비종양으로 진단된 153 명의 환자를 분석한 결과, 종양 기능성에 따른 분류에서 비기능성 종양이 흔하였고 (117명, $76.5 \%)$, 기능성 종양 중에서는 인슐린종(25명, $16.3 \%)$ 이 대부분을 차지하였다. 증상의 발현 없이 우연히 발견되는 경우는 전체 환자 중 $29.4 \%$ 였으며, 종양은 췌장 머리 부분에서 $47.7 \%$, 몸통 및 꼬리 부분에서 $52.3 \%$ 가 발생하는 것으로 조사되었다. 다발성 내분비샘 신생물(multiple endocrine neoplasia, MEN) 증후군 비율은 $1.9 \%$ 에 불과하였고, 2010년 World Health Organization (WHO) 기준에 따라 분류하였을 때 Grade 1 (G1) 98명(64.1\%), Grade 2 (G2) 37명(24.2\%), Grade 3 (G3) 18명(17.7\%) 순이었으며, Grade에 따른 2년 무질병 기간 비율은 $92 \%, 62 \%, 25 \%$ 순이었다. 췌장신경내분비종양은 진단 당시 진행된 병기를 보이더라도 예후는 췌장 선암에 비해 양호하며 진행이 느린 편으로, 내과적 치료의 목적은 종양 증식을 억제하고 증상을 조절하는 것이다. 본고에서는 췌장신경내분비종양에서 사용되고 있는 여러 가지 치료 방법 중, 내과적 치료 방법에 대해 기술하고자 한다.

\section{본 론}

\section{1. 췌장신경내분비종양의 분류}

췌장에서 기인한 신경내분비종양은 호르몬 분비에 의한 증상 발현 유무, Ki-67 분열 지수(Ki-67 proliferative index) 및 세포분화도를 기준으로 한 분류 외에도, tumor-node-metastasis
(TNM) 병기 분류를 통한 병의 진행 정도에 따라 다양한 예후를 보인다. 우선 기능성에 따른 분류에서, $50-75 \%$ 정도의 종양은 대부분은 비기능성으로 호르몬 증후군과 관련되어 있지 않다. 병기에 따른 분류에서 전이성 종양은 조사에 따라 약 $14-58 \%$ 까지 보고되고 있으며, 가장 흔한 전이 장소는 간으로 조사되고 있다..$^{4-7}$ 대부분 췌장신경내분비종양은 산발적 (sporadic)이지만, 생식세포 돌연변이에 의한 MEN 1형 및 4형, 본 히펠린다우(von Hippel-Lindau, VHL) 증후군, 신경섬유종증 1형 (neurofibromatosis type I, NF1), 결절성 경화증과 같은 다양한 유전적 내분비병증이 췌장신경내분비종양과 연관되기도 한다. ${ }^{8}$

2010년 WHO 분류에서는 저분화 신경내분비 암종(poorly differentiated neuroendocrin carcinoma)과 Ki-67 분열 지수가 높은 G3 신경내분비종양을 하나의 동일한 진단 체계로 분류하였지만, 2017년 개정된 WHO 분류에서는 구분하여 명명하였다(Table 1). ${ }^{9}$ 이는 대부분의 저분화 신경내분비 암종이 높은 Ki-67 분열지수를 보이지만, 모든 G3 신경내분비종양이 저분화 소견을 보이지 않는다는 점 그리고 일부 신경내분비종양 환자에서 조직학적으로 고분화(well differentiated) 종양이면서 Ki-67 분열 지수가 20\%보다 큰(보통 $20-55 \%)$ 경우가 보고되고 있기 때문이다. ${ }^{10}$ 이렇듯 새롭게 분류된 고분화 G3 신경내분비종양은 G2 신경내분비종양과 신경내분비 암종과 치료 반응률이나 전체 생존 기간 측면에서 차이를 보이고 있다. 가령, 고분화 $\mathrm{G} 3$ 신경 내분비종양 환자에서 기존의 백금 기반 항암화학요법을 사용하였을 때 무질병 기간은 2.4 개월로 신경내분비 암종 환자에서 관찰되는 5.0 개월과 비교하여 치료 반응률 면에서 불량하였고, ${ }^{11}$ 전체 생존 기간 측면에서는 G2 신경내분비종양과 비교하여 불량하였지만, 신경내분비 암종보다는 양호한 결과를 보였다. ${ }^{11-14}$

Table 1. WHO 2010 and 2017 Classification of NETs

\begin{tabular}{|c|c|c|c|}
\hline \multicolumn{2}{|c|}{ WHO 2010 Gastrointestinal NET classification } & \multicolumn{2}{|c|}{ WHO 2017 Pancreatic NET classficiation } \\
\hline Nomenclature & Grade & Nomenclature & Grade \\
\hline \multirow[t]{3}{*}{ NET } & G1 (Ki-67 $\leq 2 \%$ and/or $\mathrm{Ml}<2)$ & NET (well-differentiated) & G1 (Ki-67 $\leq 2 \%$ and/or $\mathrm{Ml}<2)$ \\
\hline & G2 (Ki-67 3-20\% and/or MI 2-20) & & G2 (Ki-67 3-20\% and/or MI 2-20) \\
\hline & & & $\mathrm{G} 3(\mathrm{Ki}-67>20 \%$ and/or $\mathrm{MI}>20)$ \\
\hline NEC & G3 (Ki-67 > 20\% and/or MI >20) & NEC (poorly-differentiated) & $\mathrm{G} 3(\mathrm{Ki}-67>20 \%$ and/or $\mathrm{Ml}>20)$ \\
\hline
\end{tabular}

NET, neuroendocrine tumor; G, grade; Ki-67, Ki-67 proliferation index; MI, mitotic index, mitoses/10 high power field; NEC, neuroendocrine carcinoma. 


\section{2. 췌장신경내분비종양의 치료 원칙}

치료를 선택함에 있어 증상의 유무, WHO Grade, 종양의 전이 정도 및 범위, 환자의 신체 상태 등을 고려하여 결정해야 한다. 수술로 완전 절제가 가능하다면, 수술을 우선적으로 고려해볼 수 있다. 하지만 절제 불가능한 무증상 췌장신경내분비종양에서 크기가 작은 경우에는 3-4개월 간격으로 추적 관찰을 권고하고 있는데, ${ }^{15-17}$ 이는 비기능성 진행성 신경내분비종양 환자에서 시행한 CLARINET 연구에서 lanreotide 치료군과 위약군의 무질병 기간은 차이가 있었지만, 전체 생존 기간에서는 차이가 없는 것을 근거로 한다. ${ }^{18}$ 다만, 무증상이지만 조직학적으로 고분화도를 보이면서 큰 종양 부하를 가진, 절제 불가능한 췌장신경내분비종양의 경우, 소마토스타틴 유사체(octreotide or lanreotide) 치료를 권고하고 있다. ${ }^{15-17}$ 아직까지 무증상 환자에서 소마토스타틴 유사체를 시작하는 시기에 대해서는 확립되어 있지 않다. 치료 후 진행성 또는 전이성 종양으로 악화되었을 때, 전신 치료로써 everolimus, sunitinib, temozolomide와 capecitabine 병용 치료 또는 소마토스타틴 수용체 영상이 양성일 때 방사선표적치료 (peptide receptor radionuclide therapy, PRRT) with 177Lu-dotatate 등의 치료를 고려할 수 있다. ${ }^{15-17}$

\section{3. 진행성 췌장신경내분비종양에서 사용할 수 있는 치료 약제}

진행성 또는 전이성 췌장신경내분비종양 환자에서 내과적 약물 치료의 목적은 증상을 조절하거나, 종양의 성장을 억제하는 것이다. 우선 증상 조절은 기능성 종양에서 분비되는 과도한 호르몬을 조절하거나, 이러한 호르몬 과다 분비로 인한 증상을 완화하는 것이다. 기능성 종양에서 분비되어 증상을 유발하는 호르몬을 살펴보면, 인슐린 (인슐린종), 가스트린(가스트린종), 글루카곤(글루카곤종), 혈관 작동성 장 펩티드(vasoactive intestinal peptide [VIP] 종), 소마토스타틴 (소마토스타틴종), 췌장 폴리펩티드(pancreatic polypeptide [PP] 종) 등이 있다. 종양의 성장을 억제하는 약제로는 소마토스타틴 유사체(octreotide, lanreotide), 분자 표적 치료제(everolimus, sunitinib), 항암치료(capecitabine, 5-fluorouracil, dacarbazine, oxaliplatin, streptozotocin, temozolomide) 등이 있다.

기능성 췌장신경내분비종양 중 가장 빈도가 높은 인슐린종에 대해 살펴보면, 일반적으로 인슐린종은 $1 \mathrm{~cm}$ 미만으로 크기가
작으며, $90 \%$ 이상에서 양성 종양으로 전이성 종양의 빈도는 매우 낮다. 인슐린종 환자에서 나타나는 증상은 인슐린 분비 과다와 연관이 있으며, 흔히 저혈당으로 인한 기억상실, 심계항진, 혼수 등이 동반될 수 있다. 일반적으로 인슐린종은 피낭(encapsulation)이 잘 형성되어 있어 단순종양제거술 (enucleation) 및 복강경하 제거 수술을 시도할 수 있다. 하지만 전이성 병변 등으로 수술이 제한적인 경우, 내과적 치료로써 증상 완화 및 혈당 안정화를 위해 인슐린 분비 억제제인 diazoxide, dilantin 등이나 베타세포를 파괴하는 streptozocin, 5-FU, doxorubicin을 사용할 수 있으며, 종양의 생장 억제를 위하여 고용량 소마토스타틴 유사체 또는 everolimus 투여를 고려해볼수있다.

종양 성장을 억제하는 약제 중, 현재 Food and Drug Administration (FDA), European Medicine Agency (EMA)로부터 췌장신경내분비종양의 치료 약물로 승인되어 사용되고 있는 octreotide, lanreotide, everolimus, sunitinib, streptozocin 등의 치료 약제에 대해 자세하게 살펴보도록 하겠다.

\section{1) 소마토스타틴 유사체}

소마토스타틴 유사체는 기능성 췌장신경내분비종양의 호르몬 과다 분비로 인한 증상을 조절하기 위한 목적으로 투여되며, 이 중 특히 VIP종, 글루카곤종에서 증상 조절 효과가 있는 것으로 알려져 있다. 인슐린종이나 가스트린종에서도 일부 효과가 있지만, 기존 diazoxide 및 PPI 치료에 비해 우월하지 않고, 특히 인슐린종에서는 insulin counterpart hormone인 glucagon을 함께 억제하여, 이로 인해 저혈당증이 악화될 수 있기 때문에 이차 치료 이상의 방법으로 주의해서 사용되어야 한다.

주목할 점은 소마토스타틴 유사체는 호르몬 분비와 연관된 증상 조절 목적뿐 만 아니라 항암 효과를 위해서도 사용되고 있으며, Ki-67 분열 지수가 20\% 미만인 WHO 분류기준 G1/G2 종양의 진행을 억제하는 데에 효과적인 약물로 받아들여 지고 있다. 고분화 G1/G2 종양의 경우 선암(adenocarcinoma)과 비교하여 상대적으로 세포 증식과 성장이 늦어, 기존의 고식적인 항암화학요법으로는 충분한 세포 독성 효과를 얻지 못하면서도 부작용의 발현 비율은 높았으나, 소마토스타틴 유사체는 세포 표면의 G-protein-linked receptors에 결합하여 여러 가지 기전을 통하여 호르몬 분비를 감소시킬 뿐만 아니라, 직접적인 종양 증식 억제 효과를 나타내는 것으로 보고되고 
있다. ${ }^{19}$

2000년대 들어서 진행된 두 가지 연구(PROMID와 CLARINET 연구) 결과를 근거로 소마토스타틴 유사체는 췌장신경내분비종양 억제 목적으로 사용이 승인 받게 되었다. ${ }^{18,20} \mathrm{PROMID}$ 연구에 사용된 octreotide long acting release (LAR)는 소마토스타틴보다 성장호르몬, 글루카곤 및 인슐린 분비를 더 강력하게 억제하는 것으로 알려진 최초의 소마토스타틴 유사체로서, 전이성 신경내분비종양 환자에서 위약군에 비하여 종양의 진행을 약 8개월 지연시킬 수 있음이 확인 되었다. ${ }^{20}$ CLARINET 연구는 위장관 및 췌장에서 기원한 비기능성 진행성 신경내분비종양 환자를 대상으로 lanreotide (somatuline autogel ${ }^{\mathbb{R}}$ )를 투여하여 위약군과 비교 시 무질병 기간 측면에서 의미 있는 연장을 보였으며, 이러한 결과를 통해 lanreotide가 진행성 신경내분비종양 환자에서 증상 조절뿐만 아니라 종양 성장 억제에도 효과가 있음을 입증하였다. ${ }^{18}$

부작용으로는 위장관 증상으로 복부 팽만감, 오심, 설사, 지방 흡수 불량에 따른 지방변 등이 있으나, 시간이 지나면 대부분 호전되는 것으로 알려져 있다. 다만, 소마토스타틴 유사체로 치료받는 환자 4 명 중 1 명은 담석증이 생길 수 있어, ${ }^{21,22}$ 진행된 췌장신경내분비종양 환자에서 소마토스타틴 유사체 치료가 계획되어 있는 경우, 예방적 담석 절제술 시행을 고려해야 한다. ${ }^{23}$

\section{2) 분자 표적 치료제}

앞서 기술한 바와 같이, 신경내분비종양에서 세포독성 항암화학요법은 고분화 종양 환자에서 치료 효과가 불충분하고, 부작용의 발현 비율이 높아, 표적 항암제가 새로운 치료 약제로 모색되어 왔다. National Comprehensive Cancer Network $(\mathrm{NCCN})$ 가이드라인에 따라, 분자표적치료제 중 everolimus와 sunitinib은 소마토스타틴 유사체 치료 후 진행된 WHO G1/G2 췌장신경내분비종양 환자에서 고려될 수 있다. ${ }^{24}$

\section{(1) Everolimus}

Everolimus (RAD001, Afinitor ${ }^{\mathrm{R}}$ )는 먹는 mammalian target of rapamycin (mTOR) 억제제로, 진행성 또는 전이성 췌장신경내분비종양 환자에서 1 차 치료제로 고려되는 약제 중 하나이다. mTOR은 threonine kinase로 mTOR이 활성화되면, 세포의 성장, 분열, 혈관 생성과 연관되는 특정 단백질의 생성이 증가하여, 종양의 성장 및 전이가 발생하게 되는데, everolimus는 특정 수용체인 FK-506 binding protein-12와
결합하여 mTOR complex를 억제하며 항암효과를 나타내는 것으로 알려져 있다. ${ }^{25}$ 췌장신경내분비종양 환자에서 everolimus가 치료 약제로 승인 받는 임상적 근거가 된 RADIANT-1, 2, 3, 4연구를 살펴보면, ${ }^{26-29}$ RADIANT-1, 2에서는 everolimus와 octreotide LAR를 같이 투여하였고, ${ }^{26,27}$ RADIANT-3 연구에서는 everolimus 단독으로 Grade 1/2 진행성 췌장신경내분비종양 410 명을 대상으로 진행하였다. RADIANT-3 연구에서 everolimus (10 mg, 1일 1회 경구 투약 요법) 투약 군의 무질병 기간 중앙값은 11.0 개월로 위약군의 4.6 개월과 비교해 의미 있는 치료 효과가 확인되었다. ${ }^{28}$ 또한, 폐 또는 위장관에서 기인하여 전이가 동반된 고분화 신경내분비종양 환자에서 everolimus의 유효성을 평가한 RADIANT-4 임상 결과, 위약군 대비 질병 진행 위험이 $52 \%$ 감소하였고 사망 위험 역시 $36 \%$ 감소하는 효과를 보였다. ${ }^{29}$ 부작용을 살펴보면, RADIANT-3 연구에서 Grade 3, 4 부작용은 위약과 비교하여 빈혈( $6 \%$ vs. $0 \%)$, 고혈당 $(5 \%$ vs. $2 \%)$ 과 같은 경도의 증상만 관찰되어 표적 치료제로서의 안전성도 입증되었다. ${ }^{28}$ 국내 연구에서 부작용을 살펴보면, 2002년부터 2014년까지 절제불가능한 전이성 췌장신경 내분비종양으로 진단된 40 명의 환자를 대상으로 진행된 조사에서 everolimus 투여 후 나타나는 부작용으로는 구내염이 가장 흔하였고 (47.5\%), 피부 발진(32.5\%), 빈혈(12.5\%), 설사 $(10 \%)$, 혈소판 감소증 $(7.5 \%)$ 순이었다. ${ }^{30}$ Everolimus를 투여하면서 주의하여 할 점은 기전은 아직 불분명하지만 간질성 폐렴이나 고혈당을 일으킬 수 있어, 폐질환이 있거나 당뇨가 있는 경우에는 sunitinib과 같은 다른 분자표적치료제 사용을 고려해야 하겠다.

\section{(2) Sunitinib}

Sunitinib (Sutent ${ }^{\circledR}$ )은 먹는 multi-targeted tyrosine kinase inhibitor로, VEGFR-1,2,3 및 PDGFR- $\alpha / \beta$ 등의 angiogenesis와 연관된 다양한 tyrosine kinase와 c-kit 등을 억제함으로써 종양 억제 효과를 나타내는 것으로 알려져 있다. 주로 신세포암종에 사용되고 있는 약제로, 절제 불가능하거나 국소 진행성 또는 전이성 고분화 췌장신경내분비종양 치료에도 사용이 승인되어 투여할 수 있다. ${ }^{31,32}$ Grade 1/2 진행성 췌장신경내분비종양 171 명을 대상으로 한 3상 임상 연구에서 $37.5 \mathrm{mg}$ sunitinib 투여군의 무질병 기간의 중앙값이 11.4 개월로 위약군의 5.5 개월에 비해 의미 있는 연장이 관찰되었다. 이 연구에서 추적 기간 중 두 군 모두 사망 환자가 50\%에 도달하지 않아 생존 분석이 완료되지 못하였지만, 위험비(hazard ratio)는 0.41 로 
위약에 비해 sunitinib 투여 시 사망 위험도가 낮게 관찰되었다 (95\% CI 0.19 to $0.89 ; p=0.02$ ). 또한, $9.3 \%$ 의 약제 반응률 (objective response rate)을 보임으로써 위약군의 $0 \%$ 와 현저한 차이를 확인할 수 있었다. ${ }^{31}$ Sunitinib의 약물 부작용으로는 고혈압, 호중구 감소증, 혈소판 감소증, 갑상선 기능 이상, 수족구 증후군, 심부전 등이 보고되고 있어, 심혈관 질환이나 고혈압, 출혈 경향이 있는 환자에게는 everolimus의 투여가 더 적합할 것으로 사료된다.

\section{3) 항암화학요법}

일반적으로 항암화학요법은 주로 Ki-67 분열 지수가 높거나 급속히 진행하는 종양 또는 타 장기로 전이가 동반된 경우, 다른 치료에 실패하였거나 소마토스타틴 수용체 음성인 신경내분비 암종에 우선적으로 사용이 고려되며, 주로 etoposide/cisplatin 병합 요법이 표준치료제로 받아들여지고 있다.

(1) Streptozocin-based chemotherapy (alkylating agent)

Streptozocin, dacarbazine, temozolomide은 고전적으로 사용되는 알킬화 항암제로, 단독 혹은 항 대사제(5-fluorouracil [5-FU], capecitabine)와 병용 투여할 수 있다. ${ }^{33,34}$ 국소 진행성 또는 전이성 췌장신경내분비종양 환자에서 5-FU, doxorubicin, streptozocin 병용 요법으로 치료하였을 때, $39 \%$ 의 반응률을 보였으며, ${ }^{35} 5$-FU, cisplatin, streptozocin 병용 치료 시 $38 \%$ 반응률을 보였다는 후향적 연구 결과가 있다. ${ }^{36}$

\section{(2) Temozolomide-based chemotherapy}

경구 항암제인 temozolomide는 dacarbazine의 독성을 줄여 개발한 경구용 알킬화 항암제로, 주로 재발성 뇌종양 환자에서 사용되던 약제이다. 한 2 상 연구에서 전이성 혹은 절제불가능한 저등급(low grade) 또는 중등급(intermediate grade) 췌장신경내분비종양 환자를 대상으로 temozolomide 단독과 capecitabine/temozolomide (CAPTEM) 병용 치료의 효과를 비교하였으며, CAPTEM 치료군이 22.7개월의 무질병 기간을 보여, temozolomide 단독 치료군의 14.4 개월보다 우수한 치료 성적을 보였다. ${ }^{37}$ 또한, etoposide/cisplatin에 실패한 전이성 저분화 신경내분비종양에서 2 차 약제로서 temozolomide의 효과를 평가한 한 후향적 연구에서 temozolomide 단독 또는 병합요법(capecitabine 또는 bevacizumab)은 치료 반응률 33\%, 무질병 기간 6 개월의 치료 효과를 보고하였다. ${ }^{38}$
(3) Platinum-based chemotherapy

미분화(undifferentiated) 혹은 저분화도인(poorly differentiated) 신경내분비암종(neuroendocrine carcinoma, $\mathrm{NEC})$ 의 경우, 임상적으로 급격히 진행하는 경우가 많으며, 폐소세포암(small cell lung cancer) 환자에서 투여되는 치료 약제인 cisplatin 및 carboplatin과 같은 백금 함유 항암제가 주로 사용되어 왔다. Etoposide, cisplatin 병용 치료와 관련된 연구를 살펴보면, Moertel 등 ${ }^{39}$ 이 18 명 전이성 미분화(anaplastic) 신경내분비 암종에서 전향적으로 시행한 1 차 치료 연구에서 $67 \%$ 의 반응률을 보고하였고, Mirty 등 ${ }^{40}$ 은 53 명의 신경내분비종양 환자를 대상으로 한 후향적 연구에서, 고분화 신경내분비종양 환자 11 명에서 $9.4 \%$ 반응률을 보였으나, 41 명의 저분화 암종에서는 $41.5 \%$ 반응률을 보고하였다. ${ }^{6}$ 252명의 진행성 GEP-NETs 환자를 포함한 대규모 후향적 연구에서, etoposide, cisplatin 병용 요법을 1 차 치료로 시행한 129 명의 환자에서 치료 반응률은 $31 \%$, 무질병 기간은 4 개월, 중앙 생존 기간은 12 개월로 조사되었다. Ki-67 분열 지수가 $20-55 \%$ 인 경우, $55 \%$ 이상인 경우보다 etoposide/cisplatin 병용 요법에 반응률이 떨어지는 결과를 보였으며, 이 연구 결과를 바탕으로 Ki-67 55\%라는 기준이 GEP-NETs 환자에서 기존의 항암화학요법에 대한 반응을 예측하는 기준점으로 받아들여지는 계기가 되었다. ${ }^{10}$ 추가적으로, 현재 G3 췌장신경내분비 암종에서 capecitabine/temozolomide와 etoposide/cisplatin 병용 요법을 비교하는 무작위 연구가 진행 중에 있다(NCT02595424).

\section{4) 기타}

(1) 항 PD-1 면역 항암제

전이성 고등급(high grade) 신경내분비종양으로 치료받은 환자에서 2차 약제로 항 PD-1 단일클론항체인 pembrolizumab 단독 치료의 효과를 관찰한 한 연구에서, 29 명 환자 중 1 명 $(3.4 \%)$ 에서만 부분 관해를 보였고, 무질병 기간 중앙값은 8.9 주에 불과하였으며, PD-L1 발현 여부와 치료 효과는 관련성이 없었다는 결과를 보고하였다. ${ }^{41}$ 또한, 최근 KEYNOTE-28과 KEYNOTE-158 연구에서도 진행성 췌장신경내분비종양 환자를 대상으로 pembrolizumab 투여의 효과가 각각 $6.3 \%, 7.5 \%$ 의 반응률에 머물렀다. ${ }^{42,43}$ 또다른 항 PD- 1 단일클론항체인 spartalizumab (PDR001) 단독 2상 임상 시험 예비 결과에서 33 명의 췌장신경내분비종양에서 반응률이 $3.0 \%$ 로 
관찰되었다. ${ }^{44}$ 따라서 현재까지 췌장신경내분비종양에서 면역 항암제 요법의 사용을 뒷받침 할 만한 데이터가 충분하지 않다고 하겠다. 단, 높은 현미부수체 불안정성 또는 종양
돌연변이 부하를 보이는 진행성 췌장신경내분비종양 환자에서 pembrolizumab 등 면역항암제의 치료 효과에 대해서는 향후 연구 결과를 주목해 볼 필요가 있겠다. ${ }^{45-47}$

Table 2. Drugs and insurance criteria for pancreatic neuroendocrine tumors

\begin{tabular}{|c|c|c|}
\hline Regimen & Product name & Insurance criteria \\
\hline Octreotide LAR & Sandostatin ${ }^{\circ}$ LAR & $\begin{array}{l}\text { - 시행일: 2013년 10월 1일 } \\
\text { - 투여 대상 } \\
\text { 1. 국소 치료가 불가능한 진행성 또는 전이성 분화가 좋은(well differentiated 또는 grade 1 or 2) } \\
\quad \text { 신경내분비종양 } \\
\text { - 용법/용량: } 30 \mathrm{mg} \text { 1회/4주 간격 } \\
\text { - 투여 단계/요법: 1차 이상, palliative } \\
\text { 1. 위·장·췌장계 신경내분비종양의 증상 개선 목적: 카르시노이드 증후군을 나타내는 카르시노이드 } \\
\quad \text { 종양 } \\
\text { - 용법/용량: } 120 \mathrm{mg} \text { 1회/4주 간격 }\end{array}$ \\
\hline Lanreotide acetate & $\begin{array}{l}\text { Somatuline } \\
\text { Autogel }^{\circ}\end{array}$ & $\begin{array}{l}\text { - 시행일: 2016년 4월 1일 } \\
\text { - 투여 대상: 절제불가능하고 국소진행성 또는 전이성 분화가 좋은(well differentiated 또는 grade } \\
1 \text { or 2) 위·장·췌장계 신경내분비종양 } \\
\text { - 용법/용량: } 60-120 \mathrm{mg} 1 \text { 회/4주 간격 } \\
\text { - 투여 단계/요법: } 1 \text { 차 이상, palliative }\end{array}$ \\
\hline Everolimus & Afinitor ${ }^{\circ}$ & $\begin{array}{l}\text { - 시행일: 2013년 3월 1일 } \\
\text { - 투여 대상: 절제불가능하고, grade 1, } 2 \text { 진행성 및/또는 전이성 췌장신경내분비암 } \rightarrow \text { GEP-NET로 } \\
\text { 확대(2018. 1) } \\
\text { - 용법/용량: } 10 \text { mg 1회/일 } \\
\text { - 투여 단계/요법: 1차 이상, palliative }\end{array}$ \\
\hline Sunitinib & Sutent ${ }^{\circ}$ & $\begin{array}{l}\text { - 시행일: 2013년 3월 1일 } \\
\text { - 투여 대상: 절제불가능하고, grade 1, } 2 \text { 진행성 및/또는 전이성 췌장신경내분비암 } \\
\text { - 용법/용량: } 37.5 \mathrm{mg} \text { 1회/일 } \\
\text { - 투여 단계/요법: 1차 이상, palliative }\end{array}$ \\
\hline Etoposide/Cisplatin & $\begin{array}{l}\text { Etoposide } \\
\text { Cisplatin }\end{array}$ & $\begin{array}{l}\text { - 시행일: 2006년 1월 9일 } \\
\text { - 투여 대상: 위·장·췌장계 신경내분비암 } \\
\text { - 용법/용량: etoposide } 100 \mathrm{mg} / \mathrm{m}^{2} \mathrm{D} 1-3, \text { cisplatin } 70 \mathrm{mg} / \mathrm{m}^{2} \text { D1 (3주 간격) } \\
\text { - 투여 단계/요법: 1차 이상, palliative }\end{array}$ \\
\hline $\begin{array}{l}\text { Capecitabine/ } \\
\text { Temozolomide }\end{array}$ & $\begin{array}{l}\text { Xeloda }^{\circledast} \\
\text { Temodal }^{\circledast}\end{array}$ & $\begin{array}{l}\text { - 시행일: 2011년 8월 1일 } \\
\text { - 투여 대상: 전이성 췌장신경내분비암 } \\
\text { - 급여: 사전신청요법 } \\
\text { - 용법/용량: Temozolomide } 150-200 \mathrm{mg} / \mathrm{m}^{2} \mathrm{D} 10-14 \\
\text { capecitabine } 1,500 \mathrm{mg} / \mathrm{m}^{2} \mathrm{D} 1-14 \text { (4주 간격) } \\
\text { - 투여 단계/요법: } 1 \text { 차 이상, palliative }\end{array}$ \\
\hline Irinotecan/Cisplatin & Irinotecan Cisplatin & $\begin{array}{l}\text { - 시행일: 2012년 1월 1일 } \\
\text { - 투여 대상: Extrapulmonary small cell carcinoma, stage IV에 적용 } \\
\text { - 급여: 사전신청요법 } \\
\text { - 용법/용량: Irinotecan } 60 \text { (or } 65) \mathrm{mg} / \mathrm{m}^{2} \text { IV D1, 8, (15) } \\
\text { cisplatin } 60 \mathrm{mg} / \mathrm{m}^{2} \mathrm{D} 1 \text { (or } 25 \mathrm{mg} / \mathrm{m}^{2} \mathrm{D} 1,2,3 \text { ) } \\
\text { - 투여 단계/요법: 2차 이상, palliative }\end{array}$ \\
\hline FOLFIRI & Irinotecan+leucovorin+5-FU & $\begin{array}{l}\text { - 시행일: 2020년 10월 28일 } \\
\text { - 투여 대상: Etoposide+platinum 항암요법에 실패한 신경내분비종양(grade 3) } \\
\text { - 급여: 사전신청요법 } \\
\text { - 용법/용량: Irinotecan } 180 \mathrm{mg} / \mathrm{m}^{2} \mathrm{D} 1, \text { leucovorin } 400 \mathrm{mg} / \mathrm{m}^{2} \text { (2 hr infusion) D1, } \\
\text { 5-FU } 400 \mathrm{mg} / \mathrm{m}^{2} \text { (10 min bolus) D1, 5-FU } 1,200 \mathrm{mg} / \mathrm{m}^{2} \text { (44 hr infusion) D1-D2 } \\
\text { - 투여 단계/요법: 2차 이상, palliative }\end{array}$ \\
\hline
\end{tabular}


(2) 국내 보험 기준

현재 국내에서 췌장신경내분비종양 환자의 치료를 위해 사용할 수 있는 약제를 살펴보면, 1 군 항암제로 인터페론 알파와 전신 항암제(etoposide+cisplatin, doxorubicin, etoposide+cisplatin+ifosfamide, 5-FU+interferon-alpha)가 포함되며, 2군 항암제로는 산도스타틴 유사체(octreotide LAR, lanreotide acetate), everolimus, sunitinib이 사용 가능하다(Table 2).

\section{결 론}

췌장신경내분비종양은 진행이 느린 무증상 종양, 다양한 호르몬을 분비하는 기능성 종양, 초기부터 원격 전이를 동반하는 진행성 종양까지 다양한 임상 경과를 보인다. 이에 증상 발현 유무, Ki-67 분열 지수 및 세포분화도를 기준으로 한 분류 외에도 TNM 병기 분류를 통한 병의 진행 정도에 따라 단일 또는 병용 치료를 결정하는 것이 필요하다. 내과적 약물 치료를 통해 기능성 신경내분비종양 환자에서 보이는 증상의 조절과 함께 종양 증식 억제 효과를 동시에 기대할 수 있다. Grade 1/2 진행성 혹은 전이성 췌장신경내분비종양에서 사용할 수 있는 내과적 치료 약제로는 소마토스타틴 유사체, 분자 표적 치료제, 기존의 전신 항암제 등이 있다. 전이성 췌장신경내분비 암종에서는 전신 항암제인 cisplatin 또는 carboplatin과 etoposide 병용 치료 요법 또는 temozolomide에 기초한 항암치료가 고려될 수 있다. 최근 2017년 WHO 분류기준에서 새롭게 분리된 Grade 3 췌장신경내분비종양(well differentiated, high grade) 환자군에 대해서는 아직까지 표준 치료에 대한 가이드라인이 확립되어 있지 않으며, 기존의 전신 항암제에 치료 반응률이 상대적으로 저조한 것으로 보고되고 있어 $\mathrm{G1} / \mathrm{G} 2$ 종양에서 사용되는 소마토스타틴 유사체나 분자표적치료제 등의 치료 반응률을 평가할 연구가 필요한 상황이다.

췌장신경내분비종양은 다양한 임상 경과를 보이는 만큼 다양한 치료의 선택이 필요하며, 내과적 치료뿐만 아니라 원발 부위 및 전이성 병소에 대한 근치적 절제술, 간동맥 색전술과 고주파 소작술 등의 국소 치료(liver-directed therapies), 방사선 동위 원소를 이용한 PRRT 등 모든 가능한 치료 방법을 고려하는 다학제적 접근이 중요하다고 하겠다.

\section{요 약}

췌장신경내분비종양은 랑게르한스 소도에서 기원한 종양을 의미하며, 호르몬 분비에 의한 증상 발현 유무, Ki-67 분열 지수 및 세포분화도를 기준으로 한 분류 외에도, Tumor-NodeMetastasis (TNM) 병기 분류를 통한 병의 진행 정도에 따라 다양한 예후를 보인다. 췌장신경 내분비종양의 내과적 치료 목표는 증상을 조절하거나, 종양의 성장을 억제하는 것이다. 내과적 치료 약제 중 하나인 소마토스타틴 유사체는 호르몬 분비와 연관된 증상 조절 목적뿐만 아니라 항암 효과를 위해서도 사용되고 있으며, Ki-67 분열 지수가 $20 \%$ 미만인 $\mathrm{WHO}$ 분류기준 Grade $1 / \mathrm{Grade} 2$ (G1/G2) 종양의 진행을 억제하는 데에 효과적인 약물로 받아들여지고 있다. 분자표적치료제 중 everolimus와 sunitinib은 소마토스타틴 유사체 치료 후 진행된 WHO G1/G2 췌장신경내분비종양 환자에서 고려될 수 있다. 항암화학요법은 주로 Ki-67 분열 지수가 높거나 급속히 진행하는 종양 또는 타 장기로 전이가 동반된 경우, 다른 치료에 실패하였거나 소마토스타틴 수용체 음성인 신경내분비 암종에 우선적으로 사용이 고려되며, 주로 etoposide/cisplatin 병합 요법이 표준 치료제로 받아들여지고 있다. 하지만 Grade 3 췌장신경내분비종양(well differentiated, high grade) 환자군에 대해서는 아직까지 표준 치료에 대한 가이드라인이 확립되어 있지 않으며, 기존의 전신 항암제에 치료 반응률이 상대적으로 저조한 것으로 보고되고 있어, $\mathrm{G} 1 / \mathrm{G} 2$ 종양에서 사용되는 소마토스타틴 유사체나 분자표적치료제 등의 치료 반응률을 평가할 연구가 필요한 상황이다. 췌장신경내분비종양은 다양한 임상 경과를 보이는 만큼 다양한 치료의 선택이 필요하며, 내과적 치료뿐만 아니라 원발 부위 및 전이성 병소에 대한 근치적 절제술, 간동맥 색전술과 고주파 소작술 등의 국소 치료, 방사선 동위 원소를 이용한 방사선표적치료(PRRT) 등 모든 가능한 치료 방법을 고려하는 다학제적 접근이 중요하다고 하겠다.

국문 색인: 췌장신경내분비종양, 위 · 장 · 췌장계 신경내분비종양, 신경내분비 암종, 내과적 치료

\section{Conflicts of Interest}

The authors have no conflicts to disclose. 


\section{REFERENCES}

1. Fesinmeyer MD, Austin MA, Li Cl, De Roos AJ, Bowen DJ. Differences in survival by histologic type of pancreatic cancer. Cancer Epidemiol Biomarkers Prev 2005;14:1766-1773.

2. Vinik Al, Woltering EA, Warner RR, et al. NANETS consensus guidelines for the diagnosis of neuroendocrine tumor. Pancreas 2010;39:713-734.

3. Gastrointestinal Pathology Study Group of Korean Society of Pathologists, Cho MY, Kim JM, et al. Current trends of the incidence and pathological diagnosis of gastroenteropancreatic neuroendocrine tumors (GEP-NETs) in Korea 2000-2009: multicenter study. Cancer Res Treat 2012;44:157-165.

4. Cho JH, Ryu JK, Song SY, et al. Prognostic validity of the American Joint Committee on Cancer and the European Neuroendocrine Tumors Staging Classifications for Pancreatic Neuroendocrine Tumors: a retrospective nationwide multicenter study in South Korea. Pancreas 2016;45:941-946.

5. Riihimäki M, Hemminki A, Sundquist $K$, Sundquist J, Hemminki K. The epidemiology of metastases in neuroendocrine tumors. Int J Cancer 2016;139:2679-2686.

6. Garcia-Carbonero R, Sorbye H, Baudin E, et al. ENETS consensus guidelines for high-grade gastroenteropancreatic neuroendocrine tumors and neuroendocrine carcinomas. Neuroendocrinology 2016;103:186-194.

7. Garcia-Carbonero R, Capdevila J, Crespo-Herrero G, et al. Incidence, patterns of care and prognostic factors for outcome of gastroenteropancreatic neuroendocrine tumors (GEP-NETs): results from the National Cancer Registry of Spain (RGETNE). Ann Oncol 2010;21: 1794-1803.

8. Metz DC, Jensen RT. Gastrointestinal neuroendocrine tumors: pancreatic endocrine tumors. Gastroenterology 2008;135:1469-1492.

9. Rindi G, Klimstra DS, Abedi-Ardekani B, et al. A common classification framework for neuroendocrine neoplasms: an International Agency for Research on Cancer (IARC) and World Health Organization (WHO) expert consensus proposal. Mod Pathol 2018;31:1770-1786.

10. Sorbye $H$, Welin $S$, Langer SW, et al. Predictive and prognostic factors for treatment and survival in 305 patients with advanced gastrointestinal neuroendocrine carcinoma (WHO G3): the NORDIC NEC study. Ann Oncol 2013;24:152-160.

11. Heetfeld M, Chougnet $\mathrm{CN}$, Olsen $\mathrm{IH}$, et al. Characteristics and treatment of patients with $\mathrm{G} 3$ gastroenteropancreatic neuroendocrine neoplasms. Endocr Relat Cancer 2015;22:657-664.

12. Coriat R, Walter T, Terris B, Couvelard A, Ruszniewski P. Gastroenteropancreatic well-differentiated grade 3 neuroendocrine tumors: review and position statement. Oncologist 2016;21:1191-1199.

13. Basturk O, Yang Z, Tang LH, et al. The high-grade (WHO G3) pancreatic neuroendocrine tumor category is morphologically and biologi- cally heterogenous and includes both well differentiated and poorly differentiated neoplasms. Am J Surg Pathol 2015;39:683-690.

14. Sorbye H, Strosberg J, Baudin E, Klimstra DS, Yao JC. Gastroenteropancreatic high-grade neuroendocrine carcinoma. Cancer 2014;120:2814-2823.

15. Shah MH, Goldner WS, Halfdanarson TR, et al. NCCN guidelines insights: neuroendocrine and adrenal tumors, version 2.2018. J Natl Compr Canc Netw 2018;16:693-702.

16. Pavel M, Valle JW, Eriksson B, et al. ENETS Consensus guidelines for the standards of care in neuroendocrine neoplasms: systemic therapy - biotherapy and novel targeted agents. Neuroendocrinology 2017; 105:266-280.

17. Strosberg JR, Halfdanarson TR, Bellizzi AM, et al. The North American Neuroendocrine Tumor Society Consensus Guidelines for surveillance and medical management of midgut neuroendocrine tumors. Pancreas 2017;46:707-714.

18. Caplin ME, Pavel M, Ćwikła JB, et al. Lanreotide in metastatic enteropancreatic neuroendocrine tumors. N Engl J Med 2014;371:224-233.

19. Susini C, Buscail L. Rationale for the use of somatostatin analogs as antitumor agents. Ann Oncol 2006;17:1733-1742.

20. Rinke A, Müller HH, Schade-Brittinger $C$, et al. Placebo-controlled, double-blind, prospective, randomized study on the effect of octreotide LAR in the control of tumor growth in patients with metastatic neuroendocrine midgut tumors: a report from the PROMID Study Group. J Clin Oncol 2009;27:4656-4663.

21. Ezzat S, Snyder PJ, Young WF, et al. Octreotide treatment of acromegaly. A randomized, multicenter study. Ann Intern Med 1992;117:711718.

22. Newman CB, Melmed S, Snyder PJ, et al. Safety and efficacy of longterm octreotide therapy of acromegaly: results of a multicenter trial in 103 patients--a clinical research center study. J Clin Endocrinol Metab 1995;80:2768-2775.

23. Oberg K, Kvols L, Caplin M, et al. Consensus report on the use of somatostatin analogs for the management of neuroendocrine tumors of the gastroenteropancreatic system. Ann Oncol 2004;15:966-973.

24. National Comprehensive Cancer Network. Neuroendocrine and adrenal tumor (Version 2.2020) [Internet]. Plymouth Meeting: National Comprehensive Cancer Network; 2020. Available from: https://www. nccn.org/professionals/physician_gls/pdf/neuroendocrine_blocks.pdf.

25. Atkins MB, Yasothan U, Kirkpatrick P. Everolimus. Nat Rev Drug Discov 2009;8:535-536.

26. Yao JC, Phan AT, Chang DZ, et al. Efficacy of RAD001 (everolimus) and octreotide LAR in advanced low- to intermediate-grade neuroendocrine tumors: results of a phase II study. J Clin Oncol 2008;26:43114318.

27. Pavel ME, Hainsworth JD, Baudin E, et al. Everolimus plus octreotide long-acting repeatable for the treatment of advanced neuroendocrine tumours associated with carcinoid syndrome (RADIANT-2): a randomised, placebo-controlled, phase 3 study. Lancet 2011;378: 
2005-2012.

28. Yao JC, Shah MH, Ito T, et al. Everolimus for advanced pancreatic neuroendocrine tumors. N Engl J Med 2011;364:514-523.

29. Yao JC, Fazio N, Singh $S$, et al. Everolimus for the treatment of advanced, non-functional neuroendocrine tumours of the lung or gastrointestinal tract (RADIANT-4): a randomised, placebo-controlled, phase 3 study. Lancet 2016;387:968-977.

30. Lee KJ, Cho JH, Lee SH, et al. Clinical outcomes of everolimus in patients with advanced, nonfunctioning pancreatic neuroendocrine tumors: a multicenter study in Korea. Cancer Chemother Pharmacol 2017:80:799-805

31. Raymond E, Dahan L, Raoul JL, et al. Sunitinib malate for the treatment of pancreatic neuroendocrine tumors. N Engl J Med 2011;364:501-513.

32. Raymond E, Kulke MH, Qin S, et al. Efficacy and safety of sunitinib in patients with well-differentiated pancreatic neuroendocrine tumours. Neuroendocrinology 2018;107:237-245.

33. Dilz LM, Denecke T, Steffen IG, et al. Streptozocin/5-fluorouracil chemotherapy is associated with durable response in patients with advanced pancreatic neuroendocrine tumours. Eur J Cancer 2015;51:1253-1262.

34. Clewemar Antonodimitrakis P, Sundin A, Wassberg C, Granberg D, Skogseid B, Eriksson B. Streptozocin and 5-fluorouracil for the treatment of pancreatic neuroendocrine tumors: efficacy, prognostic factors and toxicity. Neuroendocrinology 2016;103:345-353.

35. Kouvaraki MA, Ajani JA, Hoff $P$, et al. Fluorouracil, doxorubicin, and streptozocin in the treatment of patients with locally advanced and metastatic pancreatic endocrine carcinomas. J Clin Oncol 2004;22:4762-4771.

36. Turner NC, Strauss SJ, Sarker D, et al. Chemotherapy with 5-fluorouracil, cisplatin and streptozocin for neuroendocrine tumours. Br J Cancer 2010;102:1106-1112.

37. Kunz PL, Catalano PJ, Nimeiri $H$, et al. A randomized study of temozolomide or temozolomide and capecitabine in patients with advanced pancreatic neuroendocrine tumors: a trial of the ECOG-ACRIN Cancer Research Group (E2211). J Clin Oncol 2018;36(suppl 15):4004.

38. Welin S, Sorbye H, Sebjornsen S, Knappskog S, Busch C, Oberg $K$. Clinical effect of temozolomide-based chemotherapy in poorly differentiated endocrine carcinoma after progression on first-line chemotherapy. Cancer 2011;117:4617-4622.

39. Moertel CG, Kvols LK, O'Connell MJ, Rubin J. Treatment of neuroendocrine carcinomas with combined etoposide and cisplatin. Evidence of major therapeutic activity in the anaplastic variants of these neoplasms. Cancer 1991;68:227-232.

40. Mitry E, Baudin E, Ducreux M, et al. Treatment of poorly differentiated neuroendocrine tumours with etoposide and cisplatin. $\mathrm{Br} J$ Cancer 1999;81:1351-1355.

41. Vijayvergia $N$, Dasari A, Deng $M$, et al. Pembrolizumab monotherapy in patients with previously treated metastatic high-grade neuroendocrine neoplasms: joint analysis of two prospective, non-randomised trials. Br J Cancer 2020;122:1309-1314.

42. Mehnert JM, Bergsland E, O'Neil BH, et al. Pembrolizumab for the treatment of programmed death-ligand 1-positive advanced carcinoid or pancreatic neuroendocrine tumors: results from the KEYNOTE-028 study. Cancer 2020;126:3021-3030.

43. Strosberg J, Mizuno N, Doi T, et al. Efficacy and safety of pembrolizumab in previously treated advanced neuroendocrine tumors: results from the phase II KEYNOTE-158 study. Clin Cancer Res 2020;26:21242130

44. Yao JC, Strosberg J, Fazio N, et al. Activity \& safety of spartalizumab (PDR001) in patients (pts) with advanced neuroendocrine tumors (NET) of pancreatic (Pan), gastrointestinal (GI), or thoracic (T) origin, \& gastroenteropancreatic neuroendocrine carcinoma (GEP NEC) who have progressed on prior treatment (TX). Annals of Oncology 2018;29(suppl 8):viii467-viii468

45. Marabelle A, Fakih M, Lopez J, et al. Association of tumour mutational burden with outcomes in patients with advanced solid tumours treated with pembrolizumab: prospective biomarker analysis of the multicohort, open-label, phase 2 KEYNOTE-158 study. Lancet Oncol 2020;21:1353-1365.

46. Ott PA, Bang YJ, Piha-Paul SA, et al. T-cell-inflamed gene-expression profile, programmed death ligand 1 expression, and tumor mutational burden predict efficacy in patients treated with pembrolizumab across 20 cancers: KEYNOTE-028. J Clin Oncol 2019;37:318-327.

47. Xu G, Wang Y, Zhang H, She X, Yang J. Immunotherapy and potential predictive biomarkers in the treatment of neuroendocrine neoplasia [Epub]. Future Oncol 2020 Nov 2. https://doi.org/10.2217/fon-20200703 